\title{
Production Guide of Vegetable Amaranth for Florida ${ }^{1}$
}

\author{
Yuheng Qiu and Guodong Liu
}

This document is intended to provide Florida growers with a production guide for vegetable amaranth to enhance its competitiveness and boost the economy by introducing this potential cash crop to growers.

\section{General Description}

Vegetable amaranth (Amaranthus tricolor L.) is a beautiful and nutritious vegetable in the family Amaranthaceae ("Amaranthus" means "never-fading flower" in Greek) (Rastogi and Shukla 2012; Srivastava 2017). The entire Amaranthus genus has $60-80$ species, not including different subspecies and varieties (Alegbejo 2013; Ebert et al. 2011; Srivastava 2017), with the number reaching more than 110 if counting all synonyms (The Plant List 2013). These species are categorized into groups of vegetable (http://www.gardening.cornell.edu/homegardening/ scenea6a1.html), grain, ornamental, and weed (Rastogi and Shukla 2012). The vegetable type is native to tropical Asia and consists of 17 species (Ebert et al. 2011; NCSU Plant Database 2020). The most popular vegetable type species are $A$. cruentus, A. blitum, A. dubius, and A. tricolor. Other species grown as a grain crop are $A$. caudentis, $A$. cruentis, and $A$. hypochondriacus. The Amaranthus genus is widely distributed and cultivated throughout China, India, Indonesia, Japan, Pakistan, parts of the Pacific islands, tropical Africa, and tropical South America today (CABI 2020), but it is new to Florida. This article will give an overview of vegetable types of amaranth, specifically.
Amaranth has numerous common names, including Joseph's coat, garden amaranth, red amaranth, Chinese amaranth, Chinese spinach, xian cai, and fountain plant (Gilman and Howe 2014; Srivastava 2017). This vegetable has been cultivated in China for more than 400 years and has been introduced to several US states such as Mississippi and Missouri (CABI 2020; USDA-NRCS 2020). One cultivar, called 'Tampala', is found to be suitable for cultivation in the southern United States (Ebert et al. 2011). Florida's mild climate combined with amaranth's exceptional taste, nutrients, and colorful foliage suggest amaranth is a potential crop for commercial production for Florida. It is also heat tolerant and a cash crop candidate for those seeking new vegetable crops grown after potato harvesting in Florida.

\section{Propagation}

The seed of vegetable amaranth is usually brown-black in color and tiny-approximately 0.04 inches in diameter (Figure 1) (Fern 2014; USDA-NRCS 2020). Plants can be easily germinated from seed. Sow the seed one-eighth to one-quarter of an inch deep in rows and 12 to 18 inches apart (Ebert et al. 2011; Gilman and Howe 2014; NCSU Plant Database 2020). If growing in a garden, space 1 inch between each seed and thin to 6 inches apart as the plant grows (Cornell 2006). For propagation on raised beds, it is recommended to construct the bed 35 inches wide. Raise the bed 8 inches during the dry season and 20 inches during the rainy season (Ebert et al. 2011). Transplanting should be performed at the early stage of plant growth after

1. This document is HS1407, one of a series of the Horticultural Sciences Department, UF/IFAS Extension. Original publication date February 2021. Visit the EDIS website at https://edis.ifas.ufl.edu for the currently supported version of this publication.

2. Yuheng Qiu, OPS technical, MS; and Guodong Liu, associate professor, Horticultural Sciences Department; UF/IFAS Extension, Gainesville, FL 32611.

The Institute of Food and Agricultural Sciences (IFAS) is an Equal Opportunity Institution authorized to provide research, educational information and other services

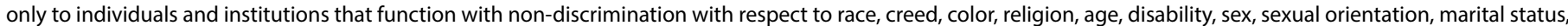

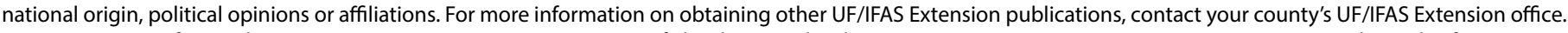
U.S. Department of Agriculture, UF/IFAS Extension Service, University of Florida, IFAS, Florida A \& M University Cooperative Extension Program, and Boards of County Commissioners Cooperating. Nick T. Place, dean for UF/IFAS Extension. 
last frost, because later transplanting may cause a premature flowering or plant limpness (Cornell 2006; Toogood 1999).

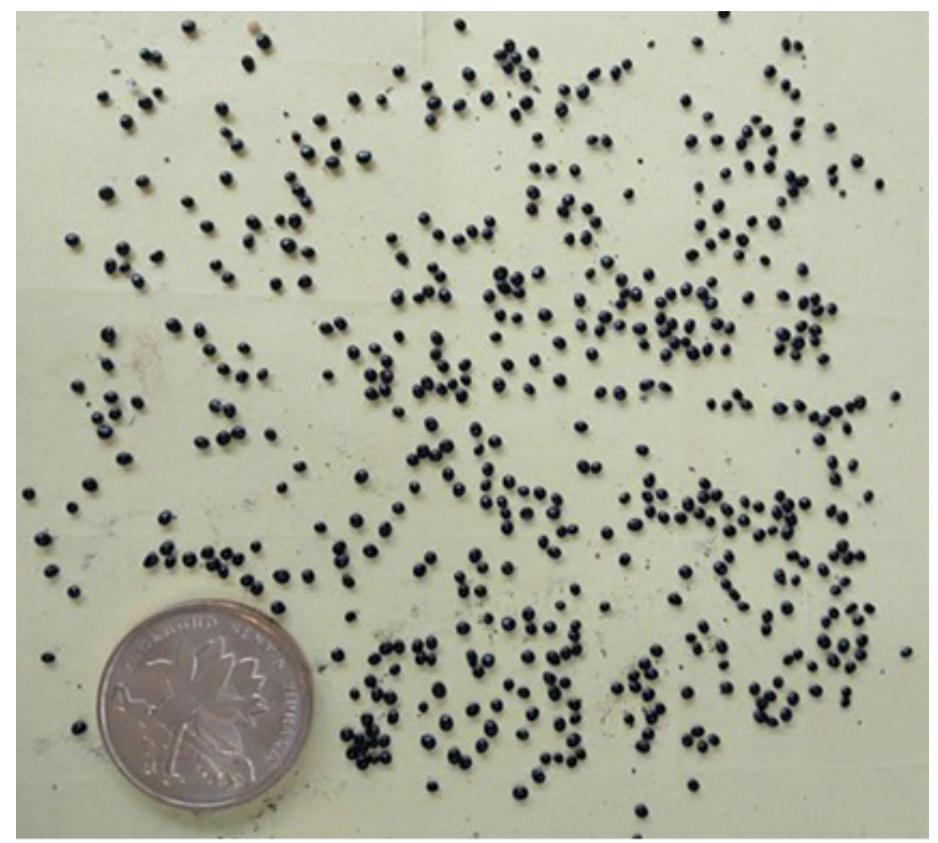

Figure 1. Vegetable amaranth seeds with a Chinese coin (0.8 inches diameter) for scale. Note the seeds' rounded shape and brown-black color.

Credits: Jianhua Li, Shuangfeng, Hunan, China

Seeds will germinate approximately one week after planting with an optimal temperature of $70^{\circ} \mathrm{F}$ to $75^{\circ} \mathrm{F}$ (CABI 2020; Cornell 2006). Germination of vegetable amaranth is rapid when soil temperature is higher than $68^{\circ} \mathrm{F}$, and the germination rate may significantly slow down or fail if soil temperature is less than $50^{\circ} \mathrm{F}$ (Cornell 2006; Fern 2014). Therefore, seed usually should be sown when soil temperature reaches $70^{\circ} \mathrm{F}$ after the last frost (Cornell 2006). The recommended earliest planting date for each USDA Plant Hardiness Zone is May for Zone 8 (north Florida), April for Zone 9 (central Florida), and from December to February for Zones 10 and 11 (south Florida) (Gilman and Howe 2014).

\section{Growing Conditions}

Although vegetable amaranth is a warm-season annual plant native to the tropics (Cornell 2006; Fern 2014), this species can potentially be grown in almost all USDA Plant Hardiness Zones from 2a to 11b (Gilman and Howe 2014; NCSU Plant Database 2020). This plant grows optimally when temperatures are between $70^{\circ} \mathrm{F}$ to $85^{\circ} \mathrm{F}$ (Cornell 2006; Fern 2014), but it can tolerate temperatures from $50^{\circ} \mathrm{F}$ to $110^{\circ} \mathrm{F}$ (Fern 2014). Plants cannot survive if the temperature is lower than $40^{\circ} \mathrm{F}$, due to chilling injury (CABI 2020; Fern 2014). Vegetable amaranth prefers full-sun cultivation, but it can tolerate partial shade if the ambient temperature is high (CABI 2020; Cornell 2006; Gilman and Howe 2014;
NCSU Plant Database 2020). Because the plant can grow to 5 feet tall and 2 feet wide, it may need staking or other support to keep the stalk upright as the plant grows (Gilman and Howe 2014; NCSU Plant Database 2020).

Although vegetable amaranth has moderate levels of drought tolerance (Gilman and Howe 2014), severe water deficiency will cause early flowering and decrease in yield (Ebert et al. 2011). This plant prefers a mean annual rainfall between 50 to 60 inches but can tolerate 10 to 110 inches (CABI 2020; Fern 2014). Irrigation plays a key role at the beginning stage of plant development (Ebert et al. 2011), but overirrigation and excessive water standing in the root zone may cause root rot (NCSU Plant Database 2020). To prevent wilting, it is recommended to regularly and evenly irrigate the soil to maintain moderate moisture (Ebert et al. 2011). Also, drip or microsprinkler irrigation are recommended for small growers, while furrow irrigation is preferred for the field practice (Ebert et al. 2011).

\section{Soil and Fertilizer}

Vegetable amaranth grows well on a wide range of soil types (Cornell 2006; Tubene and Myers 2008), preferring well-drained and fertile soil. This plant tolerates soil acidity between $\mathrm{pH} 4.3$ to 8.0 and grows optimally between $\mathrm{pH} 5.5$ to 7.0 (Cornell 2006; Fern 2014). Fertilizer application has not been shown to dramatically increase yields (Ebert et al. 2011). Excess inorganic nitrogen fertilization might result in a pale leaf and toxic nitrate accumulation in plants (Cornell 2006; Fern 2014; Gilman and Howe 2014; NCSU Plant Database 2020). Amaranth can grow well in nutrient-poor soil with appropriate fertilizer programs (Chakhatrakan 2003). There is no fertilizer recommendation available for amaranth growers in Florida. For the time being, growers can use the existing fertilizer recommendations of leaf lettuce for amaranth production: $\mathrm{pH} 6.5,150 \mathrm{lb} /$ acre of $\mathrm{N}$, 120-150 lb/acre, or $100 \mathrm{lb} / \mathrm{acre}$, for low, medium, or high soil test index using Mehlich-3 soil extractant method, respectively, and zero each of $\mathrm{P}_{2} \mathrm{O}_{5}$ and $\mathrm{K}_{2} \mathrm{O}$ (Liu et al. 2020).

\section{Pests and Diseases}

Although amaranth's colorful foliage makes it an eye-catching plant, the color can quickly fade away if proper care is not taken. This plant is susceptible to several common pests and diseases. Stem rot or wet rot caused by Choanephora cucurbitarum is the main fungal disease of concern, and white rust caused by damping-off fungi like Phytium aphanidermatum and Rhizoctonia might have deleterious effects on seedlings (CABI 2020; Ebert et al. 2011; Tubene 
and Myers 2008). Planting the seeds at an appropriate depth helps with avoiding white rust. Also, space the plants at a reasonable distance for wet rot control (PlantVillage 2020). Insects pose a threat to vegetable amaranth, particularly leaf and stem-chewing pests such as caterpillars (Spodoptera litura, Heliothis armigera, Hymenia recurvalis) and stem weevil (Hypolixus truncatulus, Lixus truncatulus) (CABI 2020; Ebert et al. 2011; Fern 2014; Mureithi et al. 2017; Stephens 2018). Traditional wood ash can be used for pest control (Ebert et al. 2011); also, uproot infested plants and remove damaged leaves to limit pest populations (PlantVillage 2020).

\section{Harvest and Storage}

Vegetable amaranth is ready for harvest approximately 30 days after planting the seeds (Ebert et al. 2011; Tubene and Myers 2008). Plants can be harvested by pulling from the soil for one-time-only harvest. For successive harvests, repeat cutting is preferred. For repeat cutting, remove a partial leaf for the first harvest to allow plants to regrow and harvest again in the next two weeks. Once the plant begins flowering, the leaves become fewer and are not suitable for harvest (Ebert et al. 2011; Tubene and Myers 2008). The foliage of vegetable amaranth may wilt rapidly due to its large surface-to-volume ratio (Ebert et al. 2011; Tubene and Myers 2008), so postharvest management, including short cooling of the plant at $40^{\circ} \mathrm{F}$ to $55^{\circ} \mathrm{F}$ with a relative humidity of $75 \%$, is recommended (Tubene and Myers 2008). Plants might quickly lose $88 \%$ of vitamin C content if stored at room temperature $\left(77^{\circ} \mathrm{F}\right)$ (Nyaura et al. 2014).

\section{Uses}

Vegetable amaranth is a leafy plant that has been widely consumed in many parts of eastern and southern Asia (Chakhatrakan 2003; Ebert et al. 2011; Srivastava 2017). In recent years, increasing consumer demand also led to a boost of sales for this vegetable in some African countries such as Kenya (Nyaura et al. 2014). Vegetable amaranth can be either eaten raw or cooked. Young, tender leaves resemble spinach, have a mild flavor, and are either eaten raw in salad mixes or stir-fried in a wok with various foodstuffs such as garlic, mushrooms, shrimp, and eggs (Figure 2) (CABI 2020; Elbert et al. 2011; Fern 2014; Tubene and Myers 2008). The soft stem can be steamed or fried the same way as asparagus (CABI 2020; Fern 2014), and its milky-white roots are often cooked with tomatoes (Ebert et al. 2011). The sprouted seeds are also edible as a nutritious addition to stews (CABI 2020; Ebert et al. 2011). Amaranth is a highly nutritious vegetable, being high in vitamins (vitamin A and C), minerals (calcium, iron, potassium), and all essential amino acids (Table 1) (Ebert et al. 2011; Fern 2014; USDA-ARS 2019). However, the leaves and stems of this plant may contain some antinutrients like nitrates and oxalates, which can bind calcium and cause kidney stones for those prone to this disease (Massey et al. 1993; Schippers 2000). These chemicals can be removed by adequate cooking but may still pose a health threat from eating the uncooked plant in excess ( $>7$ oz/day) (Alegbejo 2013; Ebert et al. 2011; Schippers 2000).

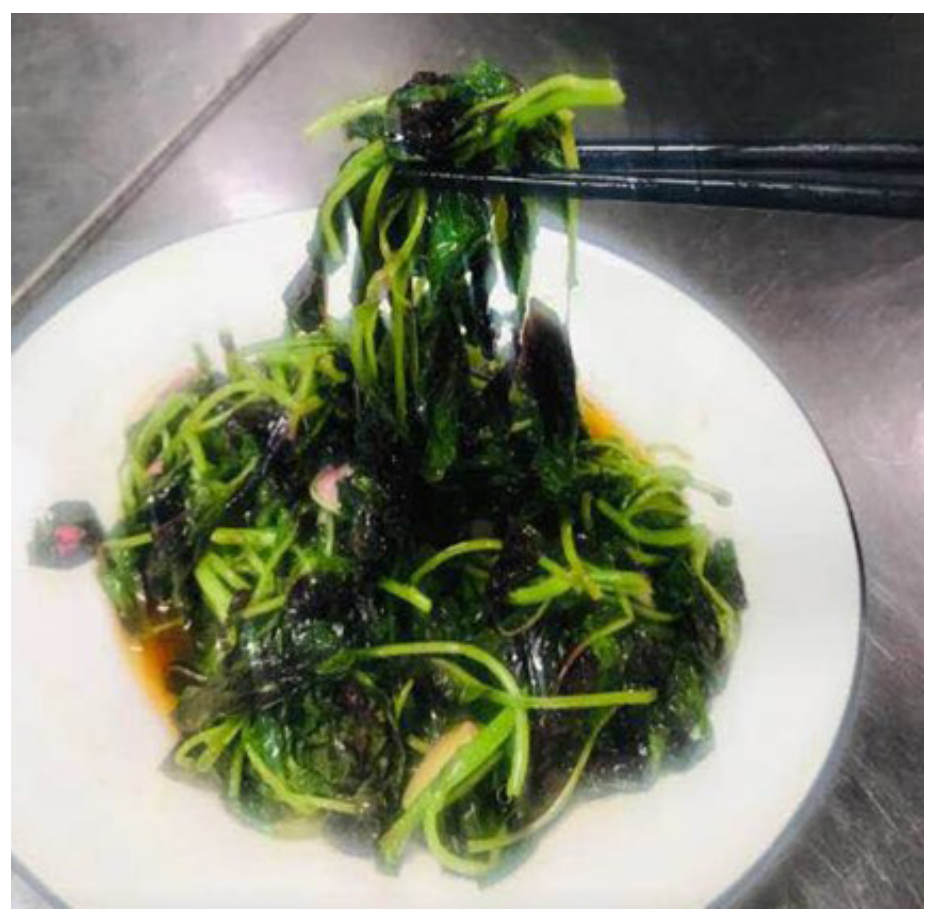

Figure 2. Wok stir-fried vegetable amaranth (Amaranthus tricolor L.) with garlic.

Credits: Xiaochun Qiu, Hefei, Anhui, China

Vegetable amaranth has been noted for its brilliantly colored and variegated foliage-red, crimson, maroon, scarlet, purple, yellow, and green-making it a popular ornamental landscape plant (Figure 3) (CABI 2020; Ebert et al. 2011; Fern 2014; Gilman and Howe 2014; NCSU Plant Database 2020; Rastogi and Shukla 2012). However, the flowers and fruits are not showy (Figure 4) (Cornell 2006; Gilman and Howe 2014; NCSU Plant Database 2020). Fortunately, there is no evidence suggesting vegetable amaranth to be invasive (CABI 2020; Gilman and Howe 2014), but it is still recommended to remove all plant materials and clean the area after harvest. Yellow and green vegetable amaranth provides a good source of yellow and green dyes (Fern 2014; Rastogi and Shukla 2012). The red betacyanin pigments from red vegetable amaranth can be used as a food colorant (Cai and Corke 1999; Cai et al. 2005). 

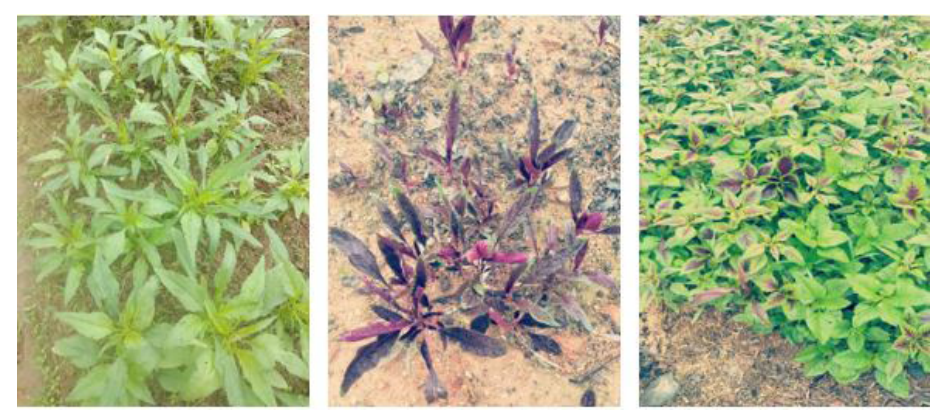

Figure 3. Vegetable amaranth (Amaranthus tricolor L.), green leaves (left), purple leaves (middle), and green-purple variegated leaves (right).

Credits: Jianhua Li, Shuangfeng, Hunan, China (left, middle), and Shuyuan Yang, Xiangxiang, Hunan, China (right)
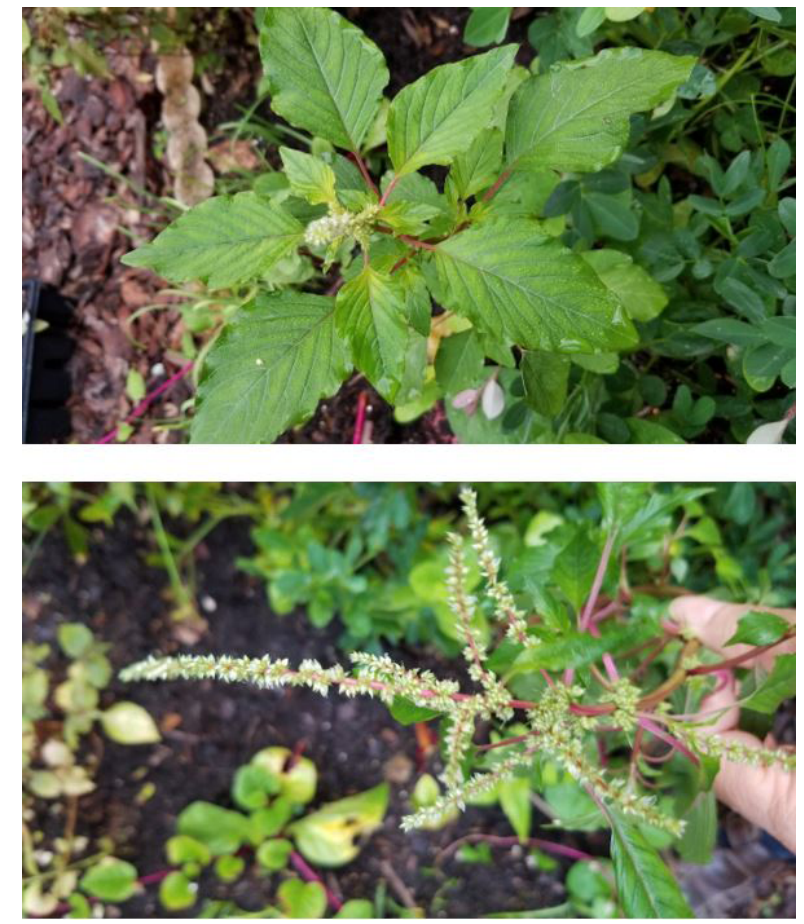

Figure 4. Vegetable amaranth (Amaranthus tricolor L.) flowers. Top: The plant starts blooming. Bottom: Two weeks after blooming started. Credits: Guodong Liu, UF/IFAS

The entire vegetable amaranth plant is laxative and diuretic (Ebert et al. 2011; Fern 2014). Vegetable amaranth has potential pharmacological properties, including antimicrobial, antioxidant, and antibacterial activities (Srivastava 2017). The polyphenolic content plays a key role in fighting free radicals (Rao et al. 2012; Srivastava 2017), and the tannin content inhibits the growth of microorganisms (Pulipati et al. 2014; Srivastava 2017).

\section{Marketability and Future Outlook}

Vegetable amaranth is commonly sold as a leafy crop at local markets in tropical and subtropical Asia (Fern 2014). In the United States, vegetable amaranth imported from Asia is available in some international grocery stores (Tubene and Myers 2008). According to the University of Maryland's
Research and Education Center, the yields of vegetable amaranth production may exceed 20,000 lb/ac (Tubene and Myers 2008). Regardless of cooking method, this tender, leafy vegetable is delicious. Because of its high nutritional value, pleasant taste, high crop yields, and adaptability to a hot climate, vegetable amaranth has great potential to be the next cash crop for Florida cultivation.

\section{Acknowledgments}

Dr. Edward Hanlon, professor emeritus, and Mary Dixon at the University of Florida reviewed the manuscript.

\section{References}

Alegbejo, J. O. 2013. "Nutritional value and utilization of Amaranthus (Amaranthus spp.)-a review." Bayero Journal of Pure and Applied Sciences 6 (1): 136-143.

Cai, Y., and H. Corke. 1999. "Amaranthus betacyanin pigments applied in model food systems." Journal of Food Science 64 (5): 869-873.

Cai, Y., M. Sun, and H. Corke. 2005. "Characterization and application of betalain pigments from plants of the Amaranthaceae." Trends in Food Science \& Technology 16 (9): 370-376.

Chakhatrakan, S. 2003. "Influence of N fertilizers on the vegetable amaranth production." Thammasat International Journal of Science and Technology 8 (4): 1-5.

Cornell University. 2006. "Explore Cornell: Home gardening flower growing guides." Cornell University Home Gardening. Accessed May 29, 2020. http://www.gardening. cornell.edu/homegardening/scenea6a1.html

Ebert, A. W., T. H. Wu, and S. T. Wang. 2011. "Vegetable amaranth (Amaranthus L.)." AVRDC-The World Vegetable Center. AVRDC Publication 11-754.

Fern, K. 2014. “Amaranthus tricolor L.” Tropical Plants Database. Accessed May 29, 2020. http://tropical.theferns. info/viewtropical.php?id=Amaranthus+tricolor

Gilman, E. F., and T. Howe. 2014. Amaranthus tricolor Joseph's Coat Amaranth, Fountain Plant. FPS038. Gainesville: University of Florida Institute of Food and Agricultural Sciences. https://edis.ifas.ufl.edu/fp038 
Liu, Guodong, Eric H. Simonne, Kelly T. Morgan, George J. Hochmuth, Shinsuke Agehara, and Rao Mylavarapu. 2020. 2020-2021 Vegetable Production Handbook: Chapter 2. Fertilizer Management for Vegetable Production in Florida. CV296. Gainesville: University of Florida Institute of Food and Agricultural Sciences. https://edis.ifas.ufl.edu/cv296

Massey, L. K., H. Roman-Smith, and R. A. Sutton. 1993. "Effect of dietary oxalate and calcium on urinary oxalate and risk of formation of calcium oxalate kidney stones." Journal of the American Dietetic Association 93 (8): 901-906.

Mureithi, D. M., K. K. M. Fiaboe, S. Ekesi, and R. Meyhöfer. 2017. "Important arthropod pests on leafy Amaranth (Amaranthus viridis, A. tricolor and A. blitum) and broadleafed African nightshade (Solanum scabrum) with a special focus on host-plant ranges." African Journal of Horticultural Science 11:1-17.

North Carolina State University. 2020. "Amaranthus tricolor." North Carolina Extension Gardener Plant Toolbox. Accessed June 2, 2020. https://plants.ces.ncsu.edu/plants/ amaranthus-tricolor/

Nyaura, J. A., D. N. Sila, and W. O. Owino. 2014. "Vitamin $\mathrm{C}$ content of vegetable amaranth during modified atmospheric storage." Proceedings of the 2013 JKUAT Scientific Technological and Industrialization Conference, November 13-14, 2013, Nairobi, Kenya. 695-699.

The Plant List. 2013. Version 1.1. Accessed June 15, 2020. http://www.theplantlist.org/tpl1.1/search?q=amaranthus

PlantVillage. 2020. “Amaranth.” Pennsylvania State University. Accessed June 11, 2020. https://plantvillage.psu.edu/ topics/amaranth/infos

Pulipati, S., P. S. Babu, and M. L. Narasu. 2014. "Quantitative determination of tannin content and evaluation of antibacterial activity of Amaranthus tricolor (L.)." International Journal of Biological \& Pharmaceutical Research 5 (7): 623-626.

Rao, K. N., S. K. Padhy, S. K. Dinakaran, D. Banji, H. Avasarala, S. Ghosh, and M. S. Prasad. 2012. "Pharmacognostic, phytochemical, antimicrobial, and antioxidant activity evaluation of Amaranthus tricolor Linn. leaf." Asian Journal of Chemistry 24 (1): 455-460.
Rastogi, A., and S. Shukla. 2013. "Amaranth: A new millennium crop of nutraceutical values." Critical Reviews in Food Science and Nutrition 53 (2): 109-125.

Schippers, R. R. 2000. African Indigenous Vegetables: An Overview of the Cultivated Species. London: University of Greenwich, Natural Resources Institute.

Srivastava, R. 2017. "An updated review on phyto-pharmacological and pharmacognostical profile of Amaranthus tricolor: A herb of nutraceutical potentials." The Pharma Innovation 6 (6): 124-129.

Stephens, J. M. 2018. Amaranth-Amaranthus spp. HS539. Gainesville: University of Florida Institute of Food and Agricultural Sciences. https://edis.ifas.ufl.edu/mv006

Toogood, R. A. 1999. Propagating Plants. London: The Royal Horticultural Society, Dorling Kindersley.

Tubene, S. L., and R. D. Myers. 2008. Ethnic and Specialty Vegetables Handbook. Second Edition. University of Maryland Extension. https://extension.umd.edu/sites/extension. umd.edu/files/_docs/EthnicVegHandbook2008.pdf

USDA-ARS. 2019. "National Nutrient Database for Standard Reference, Full Report (All Nutrients) 11004. Amaranth leaves, cooked, boiled, drained, without salt." https:// fdc.nal.usda.gov/fdc-app.html\#/food-details/169202/ nutrients

USDA-NRCS. 2020. "PLANTS profile for Amaranthus tricolor (Joseph's coat)." The PLANTS Database. Greensboro, NC: National Plant Data Team. https://plants.usda. gov/core/profile? symbol=AMTR2 
Table 1. Nutritive value of amaranth leaves (Amaranthus spp.), cooked, boiled, and drained, without salt. Source: USDA-ARS, National Nutrient Database, available at https://fdc.nal.usda.gov/fdc-app.html\#/food-details/169202/nutrients.

\begin{tabular}{|c|c|c|}
\hline Name & Amount & Unit \\
\hline \multicolumn{3}{|c|}{ Variables } \\
\hline Water & 91.49 & $g$ \\
\hline Energy & 21 & kcal \\
\hline Energy & 88 & $\mathrm{~kJ}$ \\
\hline Protein & 2.11 & $\mathrm{~g}$ \\
\hline Total lipid (fat) & 0.18 & g \\
\hline Ash & 2.11 & g \\
\hline Carbohydrate, by difference & 4.11 & $\mathrm{~g}$ \\
\hline \multicolumn{3}{|l|}{ Minerals } \\
\hline Calcium, Ca & 209 & $\mathrm{mg}$ \\
\hline Copper, Cu & 0.158 & $\mathrm{mg}$ \\
\hline Iron, Fe & 2.26 & $\mathrm{mg}$ \\
\hline Magnesium, Mg & 55 & $\mathrm{mg}$ \\
\hline Manganese, $\mathrm{Mn}$ & 0.861 & $\mathrm{mg}$ \\
\hline Phosphorus, P & 72 & $\mathrm{mg}$ \\
\hline Potassium, $\mathrm{K}$ & 641 & $\mathrm{mg}$ \\
\hline Selenium, Se & 0.9 & $\mu \mathrm{g}$ \\
\hline Sodium, $\mathrm{Na}$ & 21 & $\mathrm{mg}$ \\
\hline Zinc, Zn & 0.88 & $\mathrm{mg}$ \\
\hline \multicolumn{3}{|l|}{ Vitamins } \\
\hline Vitamin A, IU & 2770 & IU \\
\hline Vitamin A, RAE & 139 & $\mu \mathrm{g}$ \\
\hline Vitamin B-6 & 0.177 & $\mathrm{mg}$ \\
\hline Vitamin B-12 & 0 & $\mu g$ \\
\hline Vitamin C, total ascorbic acid & 41.1 & $\mathrm{mg}$ \\
\hline Vitamin D (D2 + D3) & 0 & $\mu \mathrm{g}$ \\
\hline Vitamin D (D2 + D3), International Units & 0 & IU \\
\hline Folate, total & 57 & $\mu \mathrm{g}$ \\
\hline Folic acid & 0 & $\mu \mathrm{g}$ \\
\hline Folate, food & 57 & $\mu \mathrm{g}$ \\
\hline Folate, DFE & 57 & $\mu g$ \\
\hline Niacin & 0.559 & $\mathrm{mg}$ \\
\hline Pantothenic acid & 0.062 & $\mathrm{mg}$ \\
\hline Retinol & 0 & $\mu \mathrm{g}$ \\
\hline Riboflavin & 0.134 & $\mathrm{mg}$ \\
\hline Thiamin & 0.02 & $\mathrm{mg}$ \\
\hline \multicolumn{3}{|c|}{ Amino acids } \\
\hline Alanine & 0.119 & $\mathrm{~g}$ \\
\hline Arginine & 0.104 & $\mathrm{~g}$ \\
\hline Aspartic acid & 0.196 & $\mathrm{~g}$ \\
\hline Cystine & 0.025 & g \\
\hline Glutamic acid & 0.25 & g \\
\hline Glycine & 0.113 & g \\
\hline Histidine & 0.044 & $g$ \\
\hline
\end{tabular}




\begin{tabular}{|c|c|c|}
\hline Name & Amount & Unit \\
\hline Isoleucine & 0.102 & $g$ \\
\hline Leucine & 0.167 & $g$ \\
\hline Lysine & 0.109 & $g$ \\
\hline Methionine & 0.031 & $\mathrm{~g}$ \\
\hline Phenylalanine & 0.114 & $g$ \\
\hline Proline & 0.104 & g \\
\hline Serine & 0.095 & g \\
\hline Tryptophan & 0.027 & g \\
\hline Threonine & 0.085 & $g$ \\
\hline Tyrosine & 0.068 & $g$ \\
\hline Valine & 0.118 & g \\
\hline \multicolumn{3}{|l|}{ Lipids } \\
\hline Cholesterol & 0 & $\mathrm{mg}$ \\
\hline Fatty acids, total saturated & 0.05 & g \\
\hline Fatty acids, total monounsaturated & 0.041 & g \\
\hline Fatty acids, total polyunsaturated & 0.08 & g \\
\hline Fatty acids, total trans & 0 & $g$ \\
\hline
\end{tabular}

